\title{
U6 snRNA is a Suitable Endogenous Control for microRNA-124 and -134 in Cultured Rat Hippocampal Neurons
}

(U6 snRNA adalah Kawalan Endogen yang Sesuai untuk microRNA-124 dan -134 dalam Neuron Hipokampus Tikus Berkultur)

\author{
Ai SZE CHING \& AZLINA AHMAD-ANNUAR*
}

\begin{abstract}
As researchers seek to determine the cellular mechanisms underlying biological processes, they have turned to analyze the functional role of microRNAs to understand this process in details. Here, we investigated the expression pattern of two microRNAs, miR-124 and-134 in maturing neurons and found that the choice of endogenous controls influenced the observed expression levels of these microRNAs. We have cultured rat hippocampal neurons and performed quantitative PCR on the microRNAs using Taqman gene expression assays. The expression of miRNAs was normalised with selected endogenous controls. Using BestKeeper and NormFinder software, we found that 18S rRNA and 5S rRNA to be unsuitable as endogenous controls in this system, while normalising to U6 snRNA produced more consistent results. Our study would like to highlight the importance of empirically testing proposed endogenous controls in any model system before data interpretation is carried out.
\end{abstract}

Keywords: Endogenous controls; hippocampal neuron culture; microRNAs; miR-124; miR-134

ABSTRAK

Dalam usaha untuk menentukan mekanisme sel dalam proses biologi, para penyelidik telah beralih untuk menganalisis peranan fungsi mikroRNA untuk memahami proses ini dengan lebih mendalam. Kami telah menentukan tahap ekspresi untuk dua jenis mikroRNA, miR-124 dan -134 dalam sel-sel neuron yang semakin matang dan mendapati bahawa pilihan untuk gen endogen boleh mempengaruhi tahap ekspresi yang diperhatikan untuk mikroRNA tersebut. Kami telah mengkultur sel neuron daripada hipokampus tikus dan menggunakan teknik PCR kuantitatif dengan asai ekspresi gen Taqman. Ekspresi miRNA gen telah dipenormal dengan gen endogen. Dengan menggunakan perisian BestKeeper dan NormFinder, kami mendapati bahawa rRNA 18 S dan rRNA 5S merupakan gen endogen yang tidak sesuai dalam sistem ini, manakala keputusan lebih konsisten apabila snRNA U6 digunakan. Hasil penyelidikan kami menunjukkan kepentingan untuk menggunakan pendekatan secara empirik semasa menimbangkan pilihan gen endogen yang ingin digunakan.

Kata kunci: Kawalan endogen; kultur neuron hipokampus; mikroRNAs; miR-124; miR-134

\section{INTRODUCTION}

Since the discovery of microRNAs (miRNAs), there has been an explosion of research looking at how these key players regulate gene expression. For researchers interested in the central nervous system, there is a wealth of miRNAs that are specifically expressed in the brain and spinal cord. Some miRNAs show distinct expression patterns during development and have differential temporal and spatial expression in brain regions (Bak et al. 2008; Krichevsky et al. 2003). For example, miR-103 is highly expressed throughout embryonic brain development and into adulthood (Bak et al. 2008; Krichevsky et al. 2003), while others like miR-9, are highly expressed during embryonic development, but then decrease significantly in adulthood (Krichevsky et al. 2003). Some miRnAs, like miR-7 are enriched in the pituitary gland compared to miR-479 which is more enriched in the olfactory bulb (Bak et al. 2008).
To obtain the data for expression studies, many technical variables need to be taken into consideration. The method of isolation and all 'upstream' processing of the RNA samples must be standardised to ensure that the final comparison will be an accurate representation of the expression in the cell. From tissue collection to quantification, there can be as many as five steps involved, all of which carry the potential for error. In a recent study by Wang et al. (2008), they showed that even the method of RNA isolation can result in variable results in a microarray study.

Endogenous controls are genes that are assumed to be expressed at a constant level within the cell throughout a developmental stage or during an experimental intervention. We were interested in determining the expression pattern of two miRNAs, miR-134 and -124 during synapse formation in hippocampal neurons. Previous studies had looked at the expression of these 
miRNAs using different endogenous controls (Table 1). We wondered whether the choice of endogenous control would affect the pattern of expression seen with the miRNAS

\section{METHODS}

\section{PRIMARY HIPPOCAMPAL CELLS (HPC) CULTURE}

All animal procedures were accepted by the University of Malaya Animal Ethic Committee and conformed to international standards. The protocol for culturing hippocampal cells was followed as described by Dotti et al. (1988). Briefly, hippocampi from Sprague-Dawley (SD) rats embryonic day 18.5 (E18.5) were isolated and trypsinised with $200 \mu \mathrm{L}$ of $2.5 \%$ trypsin (Gibco) together with $50 \mu \mathrm{L}$ of DNase I (Thermo Scientific). The neurons were plated on the poly-L-lysine-coated in 96-well culture plates at $1.6 \times 10^{4}$ cells per well. MEM-10 medium was used as the neuronal plating medium which containing $10 \%$ of heat-inactivated horse serum (Sigma Aldrich), $200 \mu \mathrm{L}$ of penicillin/streptomycin (Gibco), 14.5 $\mathrm{mg}$ of L-glutamine (Gibco), $5.5 \mathrm{mg}$ of sodium pyruvate (Sigma Aldrich) and topped up to $50 \mathrm{~mL}$ with Dulbecco's Modified Eagle Medium (D-MEM) (Gibco). The MEM-10 medium was replaced with Neurobasal medium when the neurons are attached on the culture plate. The hippocampal neurons were maintained in Neurobasal Medium (Gibco) supplemented with B-27 serum-free supplement (Gibco) and GlutaMAX-I (Gibco) together with $660 \mu \mathrm{L}$ of glucose (Sigma Aldrich) and $500 \mu \mathrm{L}$ of penicillin/streptomycin. Cell lysates were harvested at 2, 4, 6, 10 and 18 days in vitro (DIV) and stored in RNAlater solution (Ambion) to avoid RNA degradation. For brain-derived neurotrophic factor (BDNF) stimulation, hippocampal neurons at 4, 6

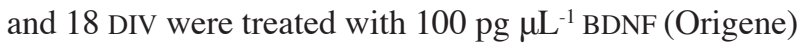
for $3 \mathrm{~h}$ at $37^{\circ} \mathrm{C}$.

\section{TOTAL RNA ISOLATION}

Total RNA from the cell lysates was isolated using the mirVana miRNA isolation kit (Ambion). The quantity and purity of the total RNA were determined using Nanodrop (Thermo Scientific) and the RNA 6000 Pico kit (Agilent) was used in conjunction with the Agilent 2100 Bioanalyzer to determine the integrity of RNA. Any total RNA which has integrity number (RIN) lower than 5 was excluded from the study.

\section{MIRNAS EXPRESSION IN CULTURED HIPPOCAMPAL NEURONS}

cDNA was synthesised from 500 ng total RNA using Taqman MiRnA Reverse Transcription kit (Applied Biosystems) together with $5 \times$ Taqman MiRnA assay stem-loop RT primers (Applied Biosystems) for miR-124 (ID: 001182) and miR-134 (ID: 001186), accordingly. For endogenous control, U6 small nuclear RNA (snRNA; ID: 001973) and
$500 \mathrm{ng} \mu \mathrm{L}^{-1}$ of universal oligo(dT) ${ }_{18}$ primer (Thermo Scientific) for $18 \mathrm{~S}$ and $5 \mathrm{~S}$ ribosomal RNA (rRNA) were used for cDNA synthesis. The amount of reverse transcription reagents were added according to the manufacturer's instructions. Once the RNA samples were added into the reverse transcription reagents, the cDNA synthesis steps were performed in a thermocycler (Applied Biosystems) according to the manufacturer's instructions. cDNA products were then kept at $-20^{\circ} \mathrm{C}$.

Quantitative PCR (qPCR) was carried out in an Applied Biosystems 7500 Fast Real-Time PCR System with 5 $\mu \mathrm{L}$ of undiluted cDNA product, $2 \times$ Maxima Probe/ ROX qPCR Master Mix (Thermo Scientific) without AmpErase UNG and 20× Taqman MiRNA assay probes (miR-124 or miR-134) or $20 \times$ Taqman U6 snRNA assay probe or $20 \times$ Taqman primers and MGB probes for 5S rRNA (forward primer: 5'-ATCTCGGAAGCTAAGCA-3'; revers primer: 5'-GGTCTCCCATCCAAGTACT-3'; MGB probe: 5'-FAM-TCGGGCCTGGT-NFQ-MGB-3') or 18S rRNA (Applied Biosystems). The amount of qPCR master mix and assay probes were added according to the manufacturer's instructions. The 96-well PCR plate was sealed with transparent adhesive film. All the Taqman assays were validated according to the Minimum Information for publication of Quantitative real-time PCR Experiments (MIQE) guidelines (Bustin et al. 2009).

The BestKeeper software (Pfaffl et al. 2004), version 1 (http://www.gene-quantification.de/bestkeeper.html) and NormFinder software (Andersen et al. 2004) (http:// moma.dk/normfinder-software), were used for validation of the endogenous controls. The BestKeeper software is an Excel-based software which utilises the raw cycle threshold $(\mathrm{Ct})$ values to evaluate the expression. For Normfinder, the $\Delta \mathrm{Ct}$ of the endogenous control was determined by using the following equation:

$$
\Delta \mathrm{Ct}=\mathrm{Ct} \text { of Time } \mathrm{X}-\mathrm{Ct} \text { of Time } 0 \text {, }
$$

where Time $\mathrm{X}$ represents any time point (i.e. 4, 6, 10 or 18 DIV) and Time 0 represents the control time point used which was 2 DIV (Livak \& Schmittgen 2001).

Studies have shown that BDNF treatment in neurons will induce gene transcription (Kang \& Schuman 1996; Schratt et al. 2004). Hence, to ensure the expression of the endogenous control was stable even after experimental manipulation, the hippocampal neurons at the 4,6 and 18 DIV time points were stimulated with $100 \mathrm{pg} \mu \mathrm{L}^{-1}$ BDNF for $3 \mathrm{~h}$ at $37^{\circ} \mathrm{C}$. The hippocampal neurons were harvested immediately after and the cell lysates were processed as mentioned earlier. Statistical analysis was done by unpaired student's T-test with $P$-value set at 0.05 .

The relative expression of miRNAs were obtained by using $2^{-\Delta \Delta \mathrm{Ct}}$. The value of $\Delta \Delta \mathrm{Ct}$ was calculated by following the equation:

$$
\begin{aligned}
\Delta \Delta \mathrm{Ct}= & \left(\mathrm{Ct}_{\text {,target }}-\mathrm{Ct}_{\text {,U6 snRNA }}\right) \text { of Time } \mathrm{X}- \\
& \left.\mathrm{Ct}_{\text {,target }}-\mathrm{Ct}_{\text {,U6 snRNA }}\right) \text { of Time } 0,
\end{aligned}
$$




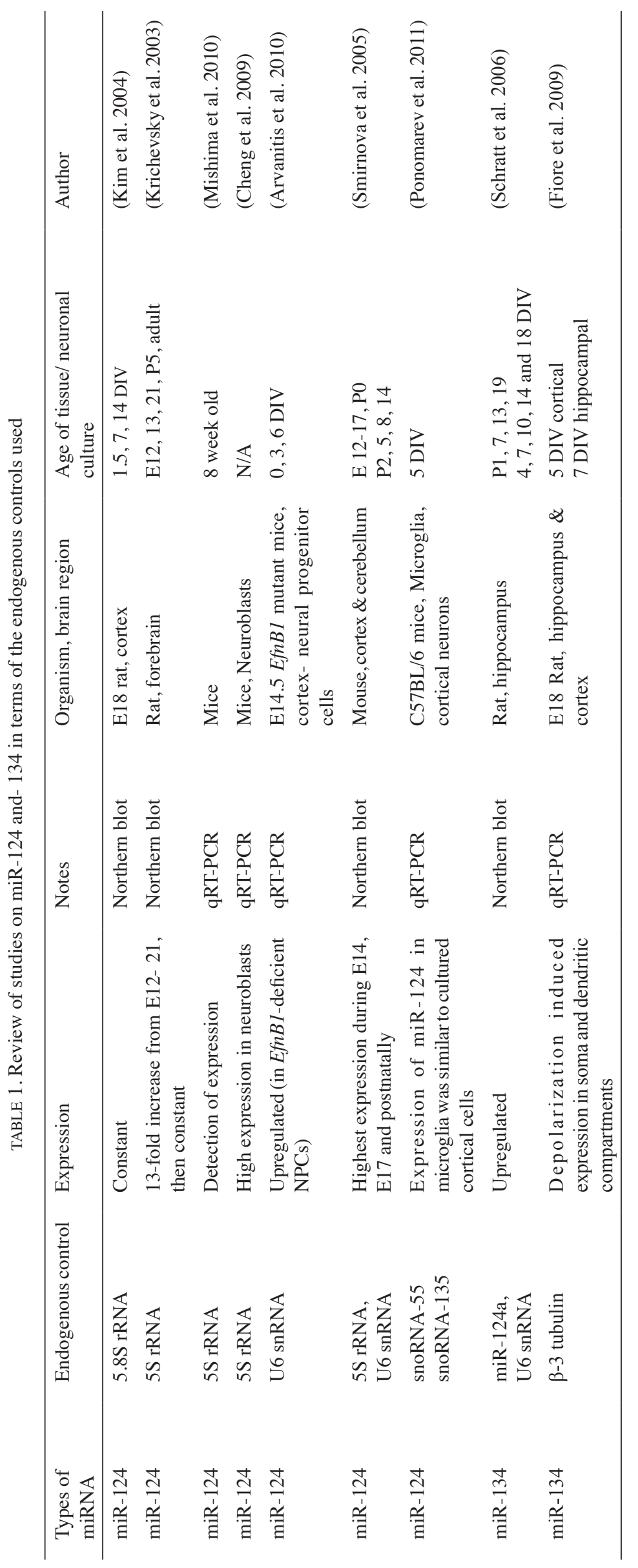


where Time $\mathrm{X}$ represents any time point (i.e. $4,6,10$ or 18 DIV) and Time 0 represents the control time point (Livak \& Schmittgen 2001).

In our study, we chose 2 DIV as our control time point in order to measure the increase in expression as the neurons mature in culture. All experiments were done at least in triplicate. Standard curves with serial dilutions for the target gene and endogenous control (18S or $5 \mathrm{~S}$ rRNAs or U6 SnRNA) were used to ensure the percentage of amplification efficiency is within 90 to $110 \%$. All slopes of the standard curves fell within $\pm 10 \%$ of -3.3 and $\mathrm{R}^{2}$ value was more than 0.98 .

\section{STATISTICAL TECHNIQUES}

Statistical analysis for real time RT-PCR data was performed by applying the independent student's T-test and one way analysis of variants (ANOVA) using the BioStat 2008 Professional analysis software.

\section{RESULTS AND DISCUSSION}

First, we performed a screen of three commonly used endogenous controls - 18S rRNA, U6 snRNA and 5S rRNA - to determine which was the most appropriate for use in a hippocampal neuron system as the neurons developed from immature neurons at 2 - 18 DIV. 5S and 18S rRNAS are one of the components of 60S (Allison et al. 1993) and 40S ribosomal subunits, respectively (Rabl et al. 2011), while U6 snRNA is part of the spliceosome (Madhani et al. 1990). These genes are present in all cell types, hence, they are the common endogenous controls used in qPCR studies (Godlewski et al. 2008; Krichevsky et al. 2003; Schratt et al. 2006). We observed a differential expression pattern of miR-134 (Figure 1) depending on which endogenous control was used. As shown in Figure 1(a), the expression of miR-134 showed constant expression from 2 to 18 DIV when normalised with $18 \mathrm{~S}$ rRNA. However with 5S rRNA (Figure 1(b)), miR-134 expression significantly increased from 2 to 10 DIV ( $P$-value: 0.011$)$ and then decreased by 18 DIV, although this decrease was not significant $(P$-value $>0.05$ ). Meanwhile, when normalised with U6 snRNA, the expression of miR-134 increased significantly from 2 to 18 DIV ( $P$-value: 0.036$)$.

When 18S rRNA was the endogenous control for miR-124, we detected a significant downregulation of its expression at 6 DIV $(P$-value: 0.039$)$ and at 10 DIV $(P$-value: 0.040 ) compared to 2 DIV (Figure 2(a)). However, this expression pattern was different when 5S rRNA was used as the endogenous control (Figure 2(b)). Here, miR-124 was seen to increase from 2 DIV to 10 DIV, although it was not (a)

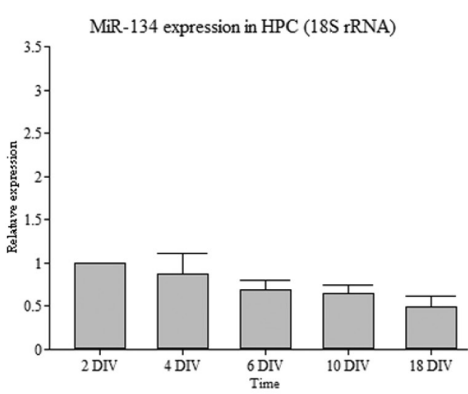

(b)

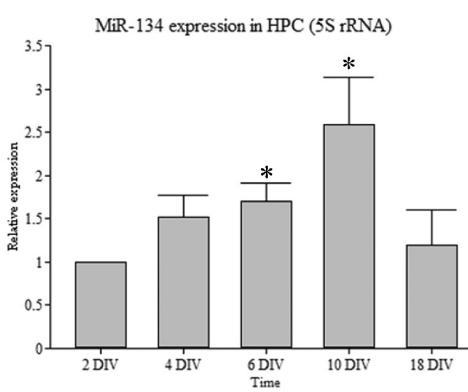

(c)

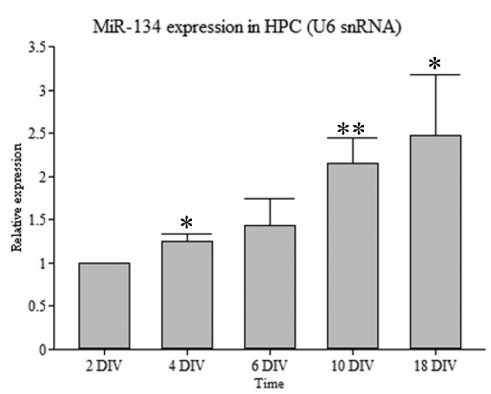

The relative expression was calculated using $2^{-\Delta \Delta C}$. The error bars of real-time RT-PCR data represent standard error of the mean of three independent experiments $(* P$-value $<0.05, * * P$-value $<0.01)$

FIGURE 1. miR-134 expression in hippocampal neurons from 2 to 18 DIV. The expression was normalised with three different endogenous controls a) 18S rRNA; b) 5S rRNA and c) U6 snRNA

(a)

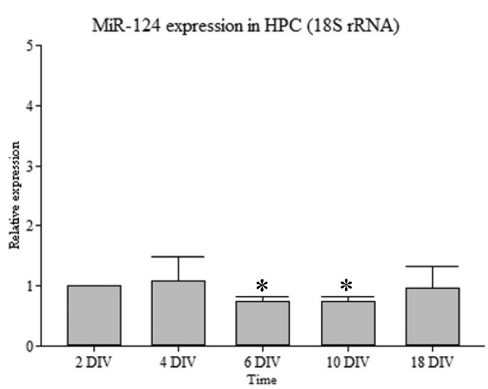

(b)

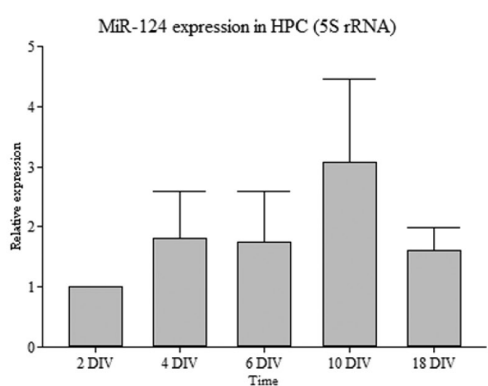

(c)

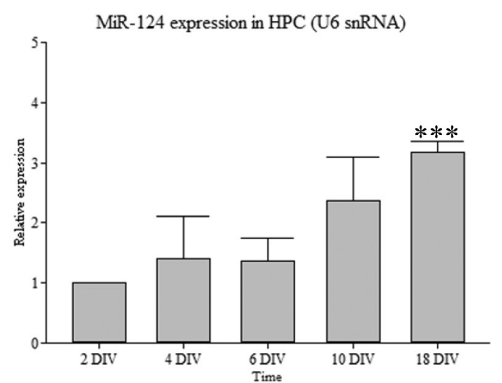

The relative expression was calculated using $2^{-\Delta \Delta \mathrm{Ct}}$. The error bars of real-time RT-PCR data represent standard error of the mean of three independent experiments. $(* P$-value $<0.05, * * * P$-value $<0.001)$

FIGURE 2. Expression of miR-124 in hippocampal neurons from 2 to 18 DIV. The expression was normalised with three different endogenous controls a) $18 \mathrm{~S}$ rRNA; b) $5 \mathrm{~S}$ rRNA and c) U6 snRNA 
significant, and then showed a decrease at 18 DIV $(P$-value $>0.05)$. In the case of U6 snRNA, miR-124 showed a trend of increasing expression from 2 to 18 DIV with a $P$-value of 0.0003 (Figure 2(c)).

The best endogenous control is thought to be the one that shows constant expression in the cells regardless of age (in culture) or experimental manipulation (e.g. addition of growth factors). However, even in the best of hands, there will be some variability in each reaction. Therefore, the general rule is that the cycle threshold $(\mathrm{Ct})$ values of the endogenous gene of interest should not be more than $10 \%$ of the mean of the Ct. Based on this, we examined the raw $\mathrm{Ct}$ value of each endogenous control for miR-134 (Figure 3(a)) and miR-124 (Figure 3(b)). The percentage of outliers in $18 \mathrm{~S}$ rRNA assay was as high as $20 \%$, compared to 5S rRNA (13.33\%) and U6 snRNA had no outliers (Table 2). Statistical analysis indicated that the $18 \mathrm{~S}$ and U6 results were reproducible ( $p$-value $>0.05$ ), while there was some indication that the $5 \mathrm{~S}$ expression was unstable ( $p$-value $<0.05)$.

(a)

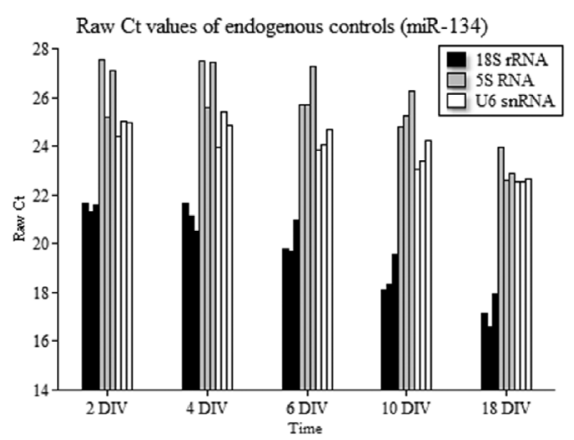

In order to confirm this finding, we validated all three endogenous controls using the BestKeeper software. Based on the evaluation by the software, any endogenous control with a standard deviation (SD) larger than 1.0 is considered to be unstable. We observed that $18 \mathrm{~S}$ rRNA and $5 \mathrm{~S}$ rRNA did not meet this criterion for either miR124 or -134 , while U6 snRNA did (Table 3). Additionally, the selection of the most stable endogenous control by BestKeeper software is also based on the lowest coefficient of variance (CV) and here, the U6 snRNA showed the lowest CV value (Table 3). As a result, U6 snRNA was selected by the BestKeeper software as the most stable endogenous control compared to the other two genes.

The NormFinder analysis tool was also used to rank the endogenous controls based on their stability values (Andersen et al. 2004). We transformed the raw $\mathrm{Ct}$ values into linear scale expression quantities using the $\Delta \mathrm{Ct}$ method and performed NormFinder analysis. The U6 SnRNA was selected as the gene with the most constant

$\mathrm{N}=3$, independent experiments for each endogenous control. The input RNA was standardised at $500 \mathrm{ng}$ for each reaction

FIGURE 3. Raw Ct values of 18S rRNA, 5S rRNA and U6 snRNA endogenous controls during a) Taqman miR-134 and b) Taqman miR-124 assays

TABLE 2. Mean Ct values of three independent experiments across all DIVs were determined

\begin{tabular}{lcccccc}
\hline & \multicolumn{2}{c}{ 18S rRNA } & \multicolumn{2}{c}{ 5S rRNA } & \multicolumn{2}{c}{ U6 snRNA } \\
& miR-134 & miR-124 & miR-134 & miR-124 & miR-134 & miR-124 \\
\hline Mean & 19.7310 & 19.3381 & 25.6511 & 24.1668 & 23.9736 \\
$+10 \%$ of mean & 21.7041 & 21.2719 & 28.2162 & 26.5835 & 26.3709 & 26.3570 \\
-10\% of mean & 17.7579 & 17.4043 & 23.0860 & 21.7502 & 21.5762 \\
\% of Outlier $(\mathrm{n}=15)$ & $13.33 \%$ & $20 \%$ & $13.33 \%$ & $6.67 \%$ & $0 \%$ \\
$P$-value & & 0.543 & & 0.0137 & 0.9375 \\
\hline
\end{tabular}

TABLE 3. Comparison of the performance of endogenous controls as evaluated by the BestKeeper software

\begin{tabular}{lcccccc}
\hline & \multicolumn{2}{c}{ 18S rRNA } & \multicolumn{2}{c}{ 5S rRNA } & \multicolumn{2}{c}{ U6 snRNA } \\
& miR-134 & miR-124 & miR-134 & miR-124 & miR-134 & miR-124 \\
\hline $\mathrm{N}$ & 15 & 15 & 15 & 15 & 15 & 0.78 \\
$\mathrm{SD}( \pm \mathrm{Ct})$ & 1.44 & 1.52 & 1.24 & 1.16 & 0.93 & 3.24 \\
$\mathrm{CV}(\% \mathrm{Ct})$ & 7.29 & 7.84 & 4.83 & 4.80 & 3.88 \\
\hline
\end{tabular}

'N': numbers of Ct value input (five time-points of three independent experiments), SD: standard deviation; CV: coefficient of variance. 
expression with the lowest stability value followed by $5 \mathrm{~S}$ rRNA and 18S rRNA (Table 4).

TABLE 4. Stability values of endogenous control as evaluated by the NormFinder software

\begin{tabular}{cc}
\hline Endogenous control & Stability value \\
\hline U6 snRNA & 0.333 \\
5S rRNA & 0.384 \\
18S rRNA & 0.586 \\
\hline
\end{tabular}

The above analyses suggested that U6 snRNA was the most suitable endogenous control for cultured hippocampal neurons amongst the three genes tested. We then tested whether the expression of U6 snRNA could be affected by BDNF treatment, as studies have suggested that some endogenous controls are sensitive to different culture conditions (Livak \& Schmittgen 2001). Upon treatment with BDNF for $3 \mathrm{~h}$, we found that there was no significant change in U6 snRNA expression compared to the untreated controls at 4,6 and 18 DIV ( $P$-value $>0.05$, Table 5$)$. Therefore, this suggests that U6 snRNA is expressed in a stable manner in hippocampal neurons.

We note that a previous study has suggested that $5 \mathrm{~S}$ rRNA and U6 snRNA are not suitable as housekeeping genes (Lim et al. 2011). However, this study was performed in cell lines which were induced into neuronal differentiation by retinoic acid, whilst our cells are primary hippocampal neurons which were not treated with any inducible factors. We found that the U6 snRNA was stable under BDNF treatment, so perhaps the issue is that U6 snRNA is affected by the retinoic acid treatment performed by Lim et al. (2011) rather than their argument that it is inconsistently expressed. Furthermore, the miRNAs that they propose as endogenous controls are not suitable in a system looking at maturing neurons undergoing synaptogenesis as the expression of these miRNAs have been reported to change in developing neurons - for miR-103 (Paschou \& Doxakis 2012) and in response to BDNF for miR-26b (Caputo et al. 2011). Meanwhile contrary to Lim et al. (2011), a study has reported that miR-106b expression changes during neuronal differentiation and it is involved in neurogenesis (Brett et al. 2011), therefore this miRNA is also not a good candidate as an endogenous control. In keeping with this, whilst we acknowledge the difference in size and abundance between miRNAs and U6 snRNA, the use of miRNAs as endogenous controls may not be without its problems as the proposed candidate miRNAs themselves may play a role in the process under investigation (in this case, synapse formation).

We propose that it is very difficult to ascertain a panel of genes that would act as consensus endogenous control genes in every cell type and condition, and this study is limited to rat hippocampal neurons. Different cell types and their response to the experimental set-up may affect the expression of these genes. Indeed when we analysed the expression of U6 snRNA using the same NormFinder analysis tool as Lim et al. (2011), we found no significant differences in our primary hippocampal neurons (with and without BDNF treatment) which contrasted with their findings that U6 snRNA was unstable in the cell lines. This difference is likely to be due to the different cell types used and the different experimental conditions. This may also explain the contrasting report by Genovesi et al. (2012) on U6 snRNA in stem cells. Most of these studies have looked at endogenous controls in neuronal differentiation in cell lines whilst our study is focused on maturing neurons involved in synapse formation.

These results have important implications in analysing the expression of the miRNAs tested. We found that when $5 \mathrm{~S}$ RNA and U6 snRNA were used, the expression of miR-134 was seen to be up-regulated during neuronal development which closely matches the expression seen by Schratt et al. (2006).

In the case of miR-124, we found that miR-124 expression appears to be more sensitive to different endogenous controls. MiR-124 has been shown to be involved in a range of neuronal roles including neurogenesis (Cheng et al. 2009) and neuronal differentiation (Makeyev et al. 2007). We found that when $18 \mathrm{~S}$ rRNA was used as a control, the expression of miR-124 appeared to be downregulated at certain time points. In contrast, when 5S rRNA was used, the expression of miR-124 had a more inconsistent pattern. Meanwhile with U6 snRNA, there was a significant increase in expression. In a previous study, Schratt et al. (2006) found that miR-124 levels were highest at 4 DIV and 7 DIV and then appeared to decrease and remain constant at lower levels from 10 - 14 DIV,

TABLE 5. Statistical analysis of real-time RT-PCR data of U6 snRNA expression in hippocampal neurons culture

\begin{tabular}{ccccc}
\hline Time & BDNF treatment & Mean & Variance & $P$-value \\
\hline \multirow{2}{*}{4 DIV } & No & 4.5345 & 0.0015 & 0.6380 \\
& Yes & 4.5557 & 0.0014 & \\
6 DIV & No & 4.4822 & 0.0014 & 0.4529 \\
& Yes & 4.5298 & 0.0039 & 0.3031 \\
\hline
\end{tabular}

The mean values were obtained from the mean of log transformed $\mathrm{Ct}$ number, and sample size equals to 3 . The $P$-value is set at 0.05 , any $P$-value which is larger than 0.05 is considered as not significant. The $P$-values were determined by independent T-test 
although there is some indication that the level increases at 18 DIV again. If we were to base our argument on U6 snRNA being the more stable endogenous control, then it appears that the expression of miR-124 is up-regulated in cultured hippocampal neurons, suggesting a significant role during maturing and matured neurons, beyond neuronal differentiation. A recent study has suggested that miR124 has a role to play in long term plasticity of mature synapses by modulating the transcriptional factor CREB (Rajasethupathy et al. 2009), which would fit in with a high expression of miR-124 in mature neurons.

\section{CONCLUSION}

We acknowledge that our study is limited as a comprehensive screen of many endogenous controls was not performed. However, this study does show that amongst the tested endogenous controls, the U6 snRNA was the most suitable for miR-124 and -134, based on two independent softwares for endogenous control selection (BestKeeper and NormFinder) - at least in a maturing neuronal system. There may be other endogenous controls that would also be suitable for these miRNAs, providing careful evaluation is performed. The authors declare no competing interests exists in the interpretation of this study.

\section{ACKNOWLEDGEMENTS}

This work was funded by a grant from the University of Malaya Research Grant program (UMRG399-12HTM) and a HIR-MOHE grant (E000029-20001). The authors acknowledge the lab members of the AAA lab for their constructive comments.

\section{REFERENCES}

Allison, L.A., North, M.T., Murdoch, K.J., Romaniuk, P.J., Deschamps, S. \& le Maire, M. 1993. Structural requirements of 5S rRNA for nuclear transport, 7S ribonucleoprotein particle assembly, and $60 \mathrm{~S}$ ribosomal subunit assembly in Xenopus oocytes. Mol. Cell. Biol. 13(11): 6819-6831.

Andersen, C.L., Jensen, J.L. \& Orntoft, T.F. 2004. Normalization of real-time quantitative reverse transcription-PCR data: A model-based variance estimation approach to identify genes suited for normalization, applied to bladder and colon cancer data sets. Cancer Res. 64(15): 5245-5250.

Arvanitis, D.N., Jungas, T., Behar,A. \& Davy, A. 2010. Ephrin-B1 reverse signaling controls a posttranscriptional feedback mechanism via miR-124. Mol.Cell Biol.30(10): 2508-2517.

Bak, M., Silahtaroglu, A., Moller, M., Christensen, M., Rath, M.F., Skryabin, B., Tommerup, N. \& Kauppinen, S. 2008. MicroRNA expression in the adult mouse central nervous system. RNA 14(3): 432-444.

Brett, J.O., Renault, V.M., Rafalski, V.A., Webb, A.E. \& Brunet, A. 2011. The microRNA cluster miR-106b 25 regulates adult neural stem/progenitor cell proliferation and neuronal differentiation. Aging (Albany NY) 3(2): 108-124

Bustin, S.A., Benes, V., Garson, J.A., Hellemans, J., Huggett, J., Kubista, M., Mueller, R., Nolan, T., Pfaffl, M.W., Shipley, G.L., Vandesompele, J. \& Wittwer, C.T. 2009. The
MIQE guidelines: Minimum information for publication of quantitative real-time PCR experiments. Clin. Chem. 55(4): 611-622.

Caputo, V., Sinibaldi, L., Fiorentino, A., Parisi, C., Catalanotto, C., Pasini, A., Cogoni, C. \& Pizzuti, A. 2011. Brain derived neurotrophic factor (BDNF) expression is regulated by microRNAs miR-26a and miR-26b allele-specific binding. PLoS One 6(12): e28656.

Cheng, L.C., Pastrana, E., Tavazoie, M. \& Doetsch, F. 2009. miR-124 regulates adult neurogenesis in the subventricular zone stem cell niche. Nat. Neurosci. 12(4): 399-408.

Dotti, C.G., Sullivan, C.A. \& Banker, G.A. 1988. The establishment of polarity by hippocampal neurons in culture. J.Neurosci. 8(4): 1454-1468.

Fiore, R., Khudayberdiev, S., Christensen, M., Siegel, G., Flavell, S.W., Kim, T.K., Greenberg, M.E. \& Schratt, G. 2009. Mef2mediated transcription of the miR379-410 cluster regulates activity-dependent dendritogenesis by fine-tuning Pumilio2 protein levels. EMBO J. 28(6): 697-710.

Genovesi, L.A., Anderson, D., Carter, K.W., Giles, K.M. \& Dallas, P.B. 2012. Identification of suitable endogenous control genes for microRNA expression profiling of childhood medulloblastoma and human neural stem cells. BMC Res. Notes 5: 507.

Godlewski, J., Nowicki, M.O., Bronisz, A., Williams, S., Otsuki, A., Nuovo, G., Raychaudhury, A., Newton, H.B., Chiocca, E.A. \& Lawler, S. 2008. Targeting of the Bmi-1 oncogene/ stem cell renewal factor by microRNA-128 inhibits glioma proliferation and self-renewal. Cancer Res. 68(22): 91259130.

Kang, H. \& Schuman, E.M. 1996. A requirement for local protein synthesis in neurotrophin-induced hippocampal synaptic plasticity. Science 273(5280): 1402-1406.

Kim, J., Krichevsky, A., Grad, Y., Hayes, G.D., Kosik, K.S., Church, G.M. \& Ruvkun, G. 2004. Identification of many microRNAs that copurify with polyribosomes in mammalian neurons. Proc. Natl. Acad Sci. USA 101(1): 360-365.

Krichevsky, A.M., King, K.S., Donahue, C.P., Khrapko, K. \& Kosik, K.S. 2003. A microRNA array reveals extensive regulation of microRNAs during brain development. RNA 9(10): 1274-1281.

Lim, Q.E., Zhou, L., Ho, Y.K., Wan, G. \& Too, H.P. 2011. snoU6 and 5S RNAs are not reliable miRNA reference genes in neuronal differentiation. Neuroscience 199: 32-43.

Livak, K.J. \& Schmittgen, T.D. 2001. Analysis of relative gene expression data using real-time quantitative PCR and the 2(-Delta Delta C(T)) Method. Methods 25(4): 402-408.

Madhani, H.D., Bordonne, R. \& Guthrie, C. 1990. Multiple roles for U6 snRNA in the splicing pathway. Genes Dev. 4(12B): 2264-2277.

Makeyev, E.V., Zhang, J., Carrasco, M.A. \& Maniatis, T. 2007. The MicroRNA miR-124 promotes neuronal differentiation by triggering brain-specific alternative pre-mRNA splicing. Mol. Cell 27(3): 435-448.

Mishima, T., Yamamoto, K., Sugimoto, T., Sakakibara, K., Uehara, A. \& Yoshii, S. 2010. Severe aortic regurgitation resulting from a downward displacement of anterior aortic annulus and fibrous strands in the bicuspid aortic valve. Ann. Thorac. Cardiovasc. Surg. 16(1): 57-59.

Paschou, M. \& Doxakis, E. 2012. Neurofibromin 1 is a miRNA target in neurons. PLoS One 7(10): e46773.

Pfaffl, M.W., Tichopad, A., Prgomet, C. \& Neuvians, T.P. 2004. Determination of stable housekeeping genes, differentially 
regulated target genes and sample integrity: BestKeeper-Excel-based tool using pair-wise correlations. Biotechnol. Lett. 26(6): 509-515.

Ponomarev, E.D., Veremeyko, T., Barteneva, N., Krichevsky, A.M. \& Weiner, H.L. 2011. MicroRNA-124 promotes microglia quiescence and suppresses EAE by deactivating macrophages via the C/EBP-alpha-PU.1 pathway. Nat. Med. 17(1): 64-70.

Rabl, J., Leibundgut, M., Ataide, S.F., Haag, A. \& Ban, N. 2011. Crystal structure of the eukaryotic 40S ribosomal subunit in complex with initiation factor 1. Science 331(6018): 730-736.

Rajasethupathy, P., Fiumara, F., Sheridan, R., Betel, D., Puthanveettil, S.V., Russo, J.J., Sander, C., Tuschl, T. \& Kandel, E. 2009. Characterization of small RNAs in Aplysia reveals a role for miR-124 in constraining synaptic plasticity through CREB. Neuron 63(6): 803-817.

Schratt, G.M., Nigh, E.A., Chen, W.G., Hu, L. \& Greenberg, M.E. 2004. BDNF regulates the translation of a select group of mRNAs by a mammalian target of rapamycinphosphatidylinositol 3-kinase-dependent pathway during neuronal development. J. Neurosci. 24(33): 7366-7377.

Schratt, G.M., Tuebing, F., Nigh, E.A., Kane, C.G., Sabatini, M.E., Kiebler, M. \& Greenberg, M.E. 2006. A brain-specific microRNA regulates dendritic spine development. Nature 439(7074): 283-289.
Smirnova, L., Grafe, A., Seiler, A., Schumacher, S., Nitsch, R. \& Wulczyn, F.G. 2005. Regulation of miRNA expression during neural cell specification. Eur. J. Neurosci.21(6): 1469-1477.

Wang, W.X., Wilfred, B.R., Baldwin, D.A., Isett, R.B., Ren, N., Stromberg, A. \& Nelson, P.T. 2008. Focus on RNA isolation: Obtaining RNA for microRNA (miRNA) expression profiling analyses of neural tissue. Biochim. Biophys. Acta 1779(11): 749-757.

Ai Sze Ching \& Azlina Ahmad-Annuar* Department of Biomedical Science, Faculty of Medicine University of Malaya, 50603 Kuala Lumpur Malaysia

*Corresponding author; email: azlina_aa@um.edu.my

Received: 21 July 2014

Accepted: 23 June 2015 